\title{
The Humanitarian Aid Field and Doctors Without Borders
}

The human rights field is not alone when it takes positions on mass violence. Other, often more powerful actors have vested interests in situations and places in which such violence occurs. Among them are national governments with geostrategic ambitions and corporations seeking profit. Since $20 \mathrm{I}_{3}$, the blockade by at least one permanent member of the UN Security Council against decisive intervention in the Assad regime's horrendous violence in Syria has provided a particularly striking, but not at all uncommon, example. Accordingly, narratives generated by governments and corporations frequently clash with human rights representations. At other times, these actors may use human rights rhetoric to disguise their pursuit of altogether different agendas.

In this and the following chapter I focus on just one potential competitor the human rights field has to contend with in its struggle for binding representations of mass violence: humanitarian aid. This field has grown immensely in recent decades as budgets for humanitarian relief, at US\$2.I billion in I990 rose to US\$I 2.9 billion in $20 \mathrm{I} 2$ (Krause 20I4:3). I ask what representations this field contributes to the world's understanding of Darfur, and how those representations relate to actions and representations proposed by the human rights sector. In Darfur, aid-oriented NGOs such as CARE (Cooperative for Assistance and Relief Everywhere) and Oxfam (Oxford Committee for Famine Relief) were well represented. In the perhaps hyperbolic words of one interviewee, staff of a humanitarian aid INGO, Darfur is the story 
of the "largest-scale humanitarian intervention that the world has ever seen. ... There were like ten thousand aid workers, like a thousand international aid workers, which is unheard of-in the Sudanese context, at least."

In this chapter I provide an in-depth analysis of the role of one particular aid-oriented INGO, Médecins Sans Frontières (MSF, or Doctors Without Borders), in the representation of Darfur. In the following chapter, I examine the role of one country that shows great affinities with the humanitarian narrative. Just as the United States took that place in the context of the human rights narrative, Ireland played a comparable role with regard to humanitarian aid-colored representations. ${ }^{\mathrm{I}}$

Humanitarian aid INGOs share all the features discussed regarding NGOs in chapter 2 . They too are part of a global civil society, members of the transnational activist networks (TAN) that Keck and Sikkink (I998) discussed in their pathbreaking work, and contributors to global scripts, in the terms of the World Polity School (e.g., Meyer, Ramirez, and Soysal 1992; Frank, Hironaka, and Schofer 2000). And their contributions reflect organizational interests, to which the constructivist tradition alerts us, just as they operate within national contexts, the impact of which Stroup (2OI2) spells out.

Yet, despite such commonalities with rights INGOs, humanitarian aid organizations occupy a distinct field. This field is engaged in a project in which agencies provide relief for a market where donors are the consumers and the beneficiaries become "part of a commodity" (Krause 20I4:4). Simultaneously, the humanitarian field is exposed to a body of international law that rules humanitarian action and for which the Geneva Convention is but one example. The field is further governed by a set of nonlegal norms, among which impartiality toward the conflicting parties and commitment to the delivery of aid to civilians stand out. In terms of social actors, this field includes a range of humanitarian organizations that coordinate the distribution of aid-and that do not typically interact with human rights NGOs. The social field of humanitarian NGOs almost always includes government actors from the very countries in which mass violence unfolds. These governments, their rulers, and front-line agents may in fact be accused by human rights NGOs for grave human rights violations and charged by international courts with human rights crimes. In the words of one of my interviewees who spoke about his work in Sudan: "I then was head of missions . . . in Sudan, based in Khartoum, which means more of the overall management of the humanitarian projects-and their representation, 
negotiation with the government and other actors. . . You negotiate with representatives of the government in order to secure the delivery of services, to have permission to have international staff in Darfur, and for the particular services as well."

In light of such particularities of the aid-oriented NGO field, and in line with Pierre Bourdieu's arguments about the impact of the structure of fields on the knowledge of its participant actors, we should expect representations of mass violence to differ markedly between humanitarian aid and human rights INGOs. In particular, we should expect different definitions of the situation in Darfur, distinct narratives of the mass violence. We should also expect conflicts over appropriate representations within the world of INGOs and within the TANs in which they are embedded.

Conflicts are likely aggravated by the distinct professional and occupational groups that dominate in human rights versus humanitarian aid fields. The dominant position of lawyers in the former and of physicians and other aid workers in the latter will almost certainly intensify divergent perspectives. ${ }^{2}$ This expectation is supported by John Hagan, Heather Schoenfeld, and Alberto Palloni (2006) in their work on mortality estimates in Darfur. They find massive differences in estimated mortality rates between public health researchers on the one hand and scholars representing a criminological perspective on the other. Estimates by the latter are substantially higher, as they are not limited to deaths from problematic health conditions in refugee and displacedperson camps, but decidedly incorporate the number of deaths that directly result from violent acts in towns, villages, and the countryside. More generally, actors in the aid field are reluctant to use the crime frame and instead apply a language of "complex humanitarian emergencies." This assessment by Hagan, Schoenfeld, and Palloni is supported by patterns Alex de Waal (I997) identified in his description-for Africa-of a complex of humanitarian NGOs and relief agencies that often engage in a consequential "strategic embrace" with the very states that commit human rights crimes.

The following sections first provide a brief overview of the history and organization of MSF, an aid-oriented NGO, but one that distinguishes itself somewhat from other aid organizations by including in its mission the duty to bear witness. Both its commonality with other aid NGOs and its distinctiveness are reflected in the organization's goals, the tensions within MSF, and especially, conflicts between MSF and other organizations. And both commonalities and distinctiveness color 
the particular types of representations that emerge, the depiction of which constitutes the core of this chapter. I finally offer a brief comparison of representations by MSF-USA with those by two rights-oriented American NGOs, thus controlling for national context. Addressing the weight of national contexts more generally leads in chapter 5 to an analysis of Ireland, the most decidedly aid-oriented country among the eight countries under investigation.

\section{THE CASE OF MSF: PRINCIPLES, ENGAGEMENT IN DARFUR, AND REPRESENTATIONS}

In I97I a group of French physicians responded to the long-standing policy of the International Committee of the Red Cross (ICRC) not to publicize government abuses of civilian populations in order to secure access to the field and to allow for the delivery of aid. Providing aid had, after all, been the ICRC's primary purpose for a century, and with its policies the Red Cross paid its dues to a field in which violent regimes always had to be accounted for. In this the ICRC, up to the present, resembles most closely the ideal type of aid-oriented NGO. The price to be paid for such neutrality became painfully clear on several occasions. One low point in the ICRC's history was its I 944 visit and "inspection" of the Nazi concentration camp of Terezin in today's Czech Republic, then in German-occupied Czechoslovakia. Instead of investigating the concentration camp system as a whole and publically displaying the inhumanity of the Nazi system, the ICRC allowed itself to be instrumentalized by the SS for legitimatory purposes. The ICRC visit at Terezin provided the Nazis with the opportunity to stage a model ghetto, carefully prepared for the occasion with clean facilities, cultural events, and cheering crowds at soccer matches. After World War II, the Red Cross stuck to its definition of neutrality by insisting on the delivery of medical and aid services to suffering populations, even if that meant keeping quiet about the horrors governments imposed on peoples under their rule. ${ }^{3}$

It was during the murderous I967-I970 civil war in Biafra in southeastern Nigeria that resistance against the dominant policy of silence emerged from within the ICRC. A small group of young French physicians, clinicians, and nurses, many of them leftist activists of the I960s, had signed up to conduct medical work in this war-torn region of Nigeria. Resenting the ICRC's restrictions on publicizing atrocities and its insistence on maintaining neutrality, they joined together with journalists 
to work toward an alternative form of organizing and engaging in aid delivery. According to MSF's self-presentation of its origins:

[Max] Recamier and [Bernard] Kouchner [members of the French group of physicians in Biafra] believed the world needed to know about the events they were witnessing: civilians being murdered and starved by blockading forces. They openly criticized the Nigerian government and the Red Cross for their seemingly complicit behavior. In the following three years, other doctors began to speak up. These doctors, or "Biafrans," as they were known, began to lay the foundations for a new and questioning form of humanitarianism that would ignore political or religious boundaries and prioritize the welfare of those suffering. ${ }^{4}$

Consequently, in December I97 I this group of physicians founded a new organization, Médecins Sans Frontières. MSF initially consisted of a rather loosely organized group of some three hundred volunteers, doctors, nurses, and other staff who were willing to simultaneously risk their lives in dangerous settings in order to provide medical help and bear witness to the horrors they observed. In subsequent years the organization became increasingly professionalized, especially after a formal decision to do so in I979. ${ }^{5}$ For twelve years after this fateful decision, MSF continued to grow under the presidency of Rony Brauman. According to its 2014 website, since I980 it has opened "offices in 28 countries and employs more than 30,000 people across the world. Since its founding, MSF has treated over a hundred million patients-with 8.3 million outpatient consultations carried out in 20 I 2 alone." 6 In I 999 the organization was awarded the Nobel Peace Prize. Clearly, MSF had grown to become one of the world's most prominent humanitarian aid NGOs.

Internationalization accompanied formalization and professionalization. MSF grew beyond its country of origin to mutate into an INGO. Returning MSF volunteers began opening chapters in their home countries, specifically in Belgium, Holland, Spain, and Switzerland. While these (operational) sections today run programs around the globe, sections in many other countries engage in the recruitment of volunteers and in fund-raising. ${ }^{7}$ An international secretariat, MSF International, links these sections and coordinates their activity. And, while each section enjoys a substantial degree of autonomy, Stroup (2012), in her study on borders among activists, nevertheless finds that the entire organization is shaped by organizational principles that reflect its origins. Like other French NGOs, MSF is almost entirely funded by private donations (about half from France). It maintains a relatively low degree 
of professionalization, despite the changes of the I980s and following decades, compared to other humanitarian NGOs such as CARE or Oxfam. Volunteers provide much of the work in section offices and in the field alike. And MSF displays a preference for outsider advocacy (movement protest strategies), rather than direct communication with government officials. The national origin of the founding organization thus continues to matter after its mutation into an INGO.

\section{Guiding Principles, Goals, and Conflicts}

Members of all MSF sections subscribe to the organization's guiding principles, enunciated on its website:

Médecins Sans Frontières provides assistance to populations in distress, to victims of natural or man-made disasters and to victims of armed conflict. They do so irrespective of race, religion, creed or political convictions. Médecins Sans Frontières observes neutrality and impartiality in the name of universal medical ethics and the right to humanitarian assistance and claims full and unhindered freedom in the exercise of its functions. Members undertake to respect their professional code of ethics and to maintain complete independence from all political, economic, or religious powers. ${ }^{8}$

Clearly, the delivery of aid is the primary mission of MSF. Yet the organization distinguishes itself from other aid NGOs as its neutrality does not require silence. James Orbinsky, then president of the MSF International Council, expressed the difference in his 1999 speech accepting the Nobel Peace Prize on the organization's behalf: "Silence has long been confused with neutrality, and has been presented as a necessary condition for humanitarian action. From its beginning, MSF was created in opposition to this assumption.... We are not sure that words can always save lives, but we know that silence can certainly kill." The French word for the program of bearing witness is témoignage. This form of witnessing is closely linked with humanitarian work in the field.

And this is the distinguishing feature of MSF among aid-oriented INGOs: the simultaneous pursuit of the goals of delivering aid and bearing witness. Such simultaneity, not surprisingly, generates conflict within the organization, and in the course of its history the pendulum has swung several times between the aid pole and the witnessing pole. In addition, conflict has plagued MSF over the purposes that bearing witness should serve. Should it encourage or legitimize "humanitarian intervention" by military means for the protection of civilian populations, criminal prosecution of perpetrators of violence, or something altogether different? 
Fabrice Weissman (20II) of MSF-France provides a minute insider's view of these tensions between and shifts in MSF's positions. A brief journey through this tormented history sets the stage for a detailed analysis of MSF's place vis-à-vis the Darfur conflict.

By the late I970s, MSF, not quite a decade old, had fully committed itself to speaking out. MSF's director announced in 1978 that staff would be "reporting human rights violations and unacceptable events they witnessed to the bureau. ... The bureau will then make an executive decision on whether to inform the public, in cases in which MSF was the sole witness" (cited in Weissman 20II:I78). In I979 and I980 MSF leadership organized and actively participated in demonstrations at the Thai-Cambodian border against inhumane policies of the proVietnamese Cambodian government. The demonstrators sought to publically display the Cambodian government's opposition to the independent distribution of food and aid in its country. In the I980s, in a broader shift toward taking political positions, MSF leaders (especially the French section) demanded a redoubling of efforts among liberal democracies against human rights abuses in Communist countries. Elsewhere MSF spoke out when it witnessed humanitarian aid contributing to criminal governmental violence and found food distribution centers becoming traps for help seekers. Ethiopia during the great famine of I985 was a case in point when the government distributed help exclusively to those willing to be resettled, thereby isolating rebels in the north of the country. MSF was expelled from the country following this campaign of témoignage.

The I990s saw the need for aid shift from refugee camps to conflict zones. Large-scale projects that required the consent of several belligerents became more common generally and in the work of MSF specifically. Somalia and Liberia are examples, while countries such as Iraq, Myanmar, and Sudan were generally opposed to interventions by western NGOs. As the UN, in this new context, increasingly authorized the use of military force to secure aid operations, MSF critiqued the international community's limiting the use of such forces to humanitarian purposes. The terms band aids for victims and humanitarian alibi were first uttered in I99I in response to "Operation Provide Comfort" in Iraq, where an international military intervention by US and French forces provided several dozen NGOs, including MSF, an opportunity to participate in the repatriation and aid programs for displaced Shiite and Kurdish populations. Later, in the Bosnian civil war, MSF conducted surveys among war refugees and eventually joined "neo-conservatives 
and liberal internationalists" to demand "that western governments conduct war against oppressive regimes rather than protect relief operations" (Weissman 20II:I86).

But the world in which MSF functioned changed, especially in the years after the Rwandan genocide. The number of international military interventions grew, including those in Kosovo, East Timor, and Sierra Leone, followed by US attacks in Afghanistan in 200I and Iraq in 2003 . UN forces became the second largest army operating in foreign countries. UN secretary-general Kofi Annan was among many who strongly supported both a new doctrine of intervention ("responsibility to protect," or $\mathrm{R}_{2} \mathrm{P}$ ) and new international institutions of criminal justice, especially the ICC. This altered environment created new concerns within MSF. The organization declared neutrality as its guiding principle in situations in which international forces were involved, and it challenged the notion of "humanitarian war." MSF was now concerned that its contributions to "exposing war crimes and misappropriations or obstruction of humanitarian assistance . . may have been encouraging the use of international military or legal measures against the perpetrators" (Weissman 20II:I92). Specifically with regard to international criminal justice interventions, important factions within MSF feared that ICC policies would convince perpetrators of war crimes, humanitarian crimes, and genocide to remove humanitarian organizations from areas of violent conflict- "especially since the [ICC] prosecutor and the NGOs supporting his actions called explicitly for humanitarian organizations to provide information to help him determine the appropriateness of launching an investigation and prepare the cases. And coupled with this controversy was a fierce debate on the political virtues of the international criminal justice system" (Weissman 20II:I92). A conflict between MSF, primarily a humanitarian aid INGO despite its mission of bearing witness, and the human rights and judicial fields was thus programmed, and it was to play itself out in the context of Darfur by affecting MSF's representations of the mass violence.

\section{Aid Delivery and Témoignage in Darfur: Between Principles and Pragmatism}

Early in $\mathbf{2 0 0 4}$, at the peak of the second major wave of mass atrocities, MSF had only a dozen workers on the ground in Darfur, providing basic assistance to some sixty-five thousand people. This was not even I percent of the population the UN estimated to be in great need of help 
at that point. MSF thus decided to speak out in order to increase international awareness of the suffering. The organization added its voice to a growing wave of international pressure exerted on the government of Sudan by NGOs, the UN, and various other governments. Specifically, MSF-France became engaged, producing a retrospective mortality survey in the internally displaced person (IDP) camps. The authors concluded that several thousand people, or 4 to 5 percent of the original population of attacked villages, had been killed during massacres. MSF thus became the first INGO to challenge the government of Sudan's insistence that no massacres had been committed.

The joint pressure on the Sudan government by a multitude of organizations was in fact followed by a substantial decline in violence by the summer of 2004 . By the winter of 2004 some I3,000 humanitarian workers, 900 of them international, were deployed by INGOs and UN agencies. Out of these, some 200 MSF expatriate volunteers served about 600,000 people in twenty-five projects. These efforts yielded substantial success. By early 2005 the mortality and malnutrition rate in the IDP camps was below the emergency threshold (Weissman 20II:I93).

Despite this success inner tension within MSF continued. On the one hand, MSF rejected the notion that genocide had occurred. MSF-France president Jean-Hervé Bradol even used the words "propagandistic distortions" (quoted in Weissman 20II:I95). On the other hand, other sections, especially MSF-Holland, were not opposed to dramatizing the situation. Its operations director declared his dissatisfaction with the aid-only approach, and Nicholas Kristof, picking up on his critique, castigated the aid-only approach in the New York Times as an "aid effort [that] is sustaining victims so they can be killed with full stomachs" (quoted in Weissman 20II:I95). In March 2005, the Dutch section published a report that documented some five hundred cases of rape committed in the context of "ethnic cleansing" campaigns and that demanded an end to impunity. This report preceded by just a few weeks the UNSC's decision to refer the case of Darfur to the ICC. But MSF had a price to pay, especially after the report was cited by Kofi Annan before the UN General Assembly. In the words of one interlocutor: "This report ["Crushing Burden of Rape"] probably would not have attracted any attention had Kofi Annan not quoted from it on World Women's Day, March 9, $2005, \ldots$ in a speech before the General Assembly. Through that the report immediately found widespread attention. Our head of mission and deputy head of mission were arrested shortly thereafter and interrogated by the Sudanese authorities. They 
were then locked up for several days because of this report" (author's translation).

The price to be paid by MSF was to increase in 2009 when the French and Dutch sections were expelled from Sudan just after President alBashir was indicted by the ICC. The government of Sudan accused them of breaking the principle of neutrality and collaborating with the ICC and in fact providing it with evidence. Later the Swiss section withdrew from Darfur.

Fabrice Weissman summarizes MSF's compromise position and the lessons drawn from the Darfur experience:

Afraid of being seen as a stake-holder in legal or military processes, and thus compromise its access to conflict zones, it [MSF] tends to let other international actors speak for it, hoping to distinguish itself as the language police by tracking down misuses of humanitarian semantics. . . If it wants to offer impartial, effective aid, MSF must distance itself equally from the liberal imperialism of the societies of its origins and the despotism of many of the countries where it intervenes. Experience has shown that it can only succeed with the support of political and diplomatic coalitions of convenience, rallied through an engagement in the public space, without which humanitarianism is only a passive instrument in the service of power (Weissman 20II:I96-I97).

Clearly, MSF takes a particular position in the humanitarian field. Different from organizations such as CARE, it insists on independence from states and avoids what Bourdieu would call, in the tradition of Durkheimian sociology, pollution of its very principles. It also keeps a distance from religious fields, unlike the Irish aid organizations discussed in the following chapter. Its témoignage principle helps it maintain independence from host countries such as Sudan, but it moves the organization closer to nonstate political actors, potentially exposing it to "movement pollution" (Krause 20I4:II2-II3). Conflicts between témoignage and functional pressures of aid delivery result in internal struggles and occasional shifts in emphasis. Cultural anthropologist Peter Redfield (2013), after extensive field research with MSF, indeed finds "an internal culture of reflection, debate and critique" (36; see also Bortolotti 20I0). MSF's position as a player in the humanitarian aid field and its particularities within that field should be reflected in the minds of its actors when they speak about Darfur, and it should color their narratives of the violence. I expect greater caution than among human rights NGOs, but more outspokenness than found in narratives of other aid NGOs. 


\section{VIEWS FROM THE FIELD: INTERVIEWS AND DATA}

How, then, are the statements of purpose cited above and the conflicts between témoignage and delivering aid reflected in the minds of MSF workers? What strategies do they find useful in dealing with them? Finally, what representations of the Darfur conflict grow out of this field? How do they reflect the habitus of those who occupy it?

During my travels across Europe and North America I conducted interviews with eight MSF staff members in five countries, supplementing the statistical analysis of the MSF-USA website and those of other American NGOs. I approached the different sections and inquired about staff with particular expertise on Darfur. In some cases I contacted specific individuals who had been recommended by staff in other sections. A noticeable caution among MSF workers was associated with a relatively high rejection rate in response to requests for interviews, higher, for example, than among Amnesty activists. Several who declined interview requests referenced the sensitive situation in Darfur. ${ }^{9}$ This is not surprising given the history of arrests and kidnappings of MSF workers in Sudan, the expulsion and withdrawal of three of MSF's five operational sections, and the continuing work of two sections in the field of Darfur.

Those who did agree to be interviewed were of diverse professional background: two staff with medical degrees and one with some medical training; one lawyer who specializes in international law, with degrees also in philosophy and development; one activist who had abandoned legal training and switched to political science with a focus on African studies; one political scientist with a degree in history; one staff member with journalism training; and one with an engineering degree and some training in management and journalism. The interviewees' positions within MSF also differed. Most respondents had experienced a variety of placements in the course of their MSF careers: a former longterm president of his section, now a researcher and consultant; an MSF project coordinator, previously a field coordinator in Khartoum; one project manager in an operational center; a previous head of mission in Sudan, now a project supervisor; one general director of a national section; one program manager; one head of personnel affairs in his section; and one manager for medical and humanitarian communication who had previously served as a press officer. All but two had experienced deployments in Sudan. In terms of national affiliation, three interviewees were located in the Paris office, one in Geneva, one each in London 
and Vienna, and two in the US office in New York City. In three cases the interviewee's nationality differed from that of the section for which she or he worked.

\section{GOALS AND GOAL CONFLICTS AS EXPERIENCED AT THE FRONT LINES}

Not surprisingly, all MSF respondents, when asked about four potentially competing goals to be pursued in Darfur (i.e., aid, justice, peace, state sovereignty), highlighted—or at least included —-the delivery of aid or humanitarian assistance; or they used some other wording to describe this central mission of an aid-oriented NGO. One interviewee urged "modesty": "Our priorities were clearly to be able to provide, to respond to those needs, to do so in a relevant, evidently independent way, with the goal of alleviating some of the suffering." Another respondent also focused on alleviating suffering but stressed that this goal may be reached through aid delivery and also through bearing witness: "For me the goal would be first and foremost to help the largest part of the population to survive the war. This means humanitarian assistance, but this also means pressure on the government not to unleash its army or its militias as it did in 2003 and 2004." To this respondent the missions to exert pressure by bearing witness and to secure survival did not appear contradictory. Pressure on governments, for example, by publicizing atrocities, may in fact be a precondition for the delivery of aid. Another interviewee who acknowledged the tension between diverse goals argued that securing survival may be a precondition for justice at some later point:

As a humanitarian organization we are not pacifists. And we sort of take for granted that wars will erupt. But that people should not pay with their lives. Civilians and non-combatants should not pay with their lives when there is a breakdown in the political process that leads to war. So we try to maximize our operational space to see how much aid we can deliver to people, to restore them to their capacity for choice. And then it is their choice what they want to do in terms of pursuing justice.

Simultaneously, the notion of conflict between the delivery of aid and international criminal justice is deeply ingrained in the minds of my interviewees. The eviction of two MSF sections from Darfur, following the issuing of the 2009 arrest warrant against President al-Bashir and the arrest and interrogations of two MSF leaders in Sudan after 
the release of the 2005 rape report, in all likelihood contributed to this sense of antagonism. One project manager, a learned physician, described the conflict as follows:

In March 2009, with the ICC decision, I think it had a big impact on the conflict and on many issues. You know of course that it resulted in the expulsion of many NGOs immediately from Darfur. And not only that, but it really was the beginning or at least the visible beginning of the attempt by the Sudanese government of domesticating the Darfur crisis-a deliberate strategic policy to reclaim ownership over Darfur, [to] try to remove international influence in Darfur. It was the straw that broke the camel's back. . . I I think for many years the Khartoum government has been troubled by international influence on what they see as their affairs. I have talked with ministers, with the Sudanese ambassador to the US; . . . they said very clearly these things. Another word they use is "Sudanization," the Sudanization of humanitarian aid. ... That's a term that people in the government in Khartoum use, "Sudanization of aid." It's coming from Bashir. . . . It's not just expulsion from the country; it's also the restriction of work in Darfur. ... One of our MSF teams was kidnapped, early-I think it was two weeks after the ICC decision.

MSF workers who highlight the conflict between MSF and the ICC also tend to cast more general doubt on the ICC. I encountered this (conscious or unconscious) strategy of rationalizing the MSF position toward the ICC in several interviews. One respondent, for example, spoke to the uneven risk countries run of seeing their leaders indicted by the ICC. He pointed to the many nation-states, including some of the most powerful, that have not ratified the Rome Statute and concluded: "It is not an even playing field to begin with. I understand completely: a lot of people would disagree with me. But it's not just my opinion. In MSF there is an article that you can get online by Fabrice Weissman on the ICC; it is called 'grounds for divorce,' between MSF and ICC."

Indeed, the general skepticism of some MSF actors against the ICC is articulated on the MSF website, and its message appears to resonate with many in the organization. Another interviewee became more concrete while expressing similar skepticism:

As a citizen I am skeptical that it [ICC] is just going to be a tool that the wealthy, powerful countries use to bludgeon whatever enemy they determine of that day. I mean I won't believe in the ICC until Henry Kissinger is in the dock. I mean if you are going to talk about a breach of international conventions and war crimes etc., I mean, Henry Kissinger should be at the top of anyone's list. Or John Yoo, for example; I mean, how do you write a torture memo like that? 
In addition to casting doubts on the equal treatment of different countries before the ICC, one other MSF interviewee challenged the notion of justice in the international realm in principle: "I have a problem with international justice due to the fact that I think justice, I mean judicial justice, so to speak, is not a proper way to judge mass crimes.... Of course, justice, I mean a trial, can bring more knowledge. It is obvious. But factual knowledge is not the overall understanding of a criminal or a violent process that is going on. . . I think it is misleading, it is a misleading device." This respondent supplemented his general critique of international criminal justice with that of particular personnel, especially the ICC chief prosecutor at the time, Luis Moreno-Ocampo. He also stressed, though, that his critique reflected his personal philosophy (albeit one influential within MSF), and that MSF, for good reason, had no official position on the ICC.

Despite such broad skepticism, MSF actors on the ground contribute through their practice to the potential for criminal justice intervention, and they may be mindful of that contribution. The interviewee cited above as having intense skepticism concerning the ICC's equal treatment of different countries spoke about strategies for providing proof for future criminal justice proceedings:

I don't think it is a binary opposition [between aid and justice] personally.... You know, victims of sexual violence are able to receive a [medical] certificate, in case they want to bring some judicial proceedings against the perpetrators of that sexual violence. They have used that.... [In Congo] the judiciary had just started to function in a kind of independent fashion. And lo and behold, ... like fifty women in this same rural Congo village came and testified against the police officers that had raped them.

Another respondent, who had listed aid delivery as the organization's primary aim, nevertheless offered an additional strategy-linking the delivery of medical assistance to measures that may contribute to others' responses in the pursuit of peace or justice. It is worth quoting at length from his discussion:

One is always on the safe side if one does not repeat things others have told, but testifies directly. If I have someone, and there were such cases, where shooting wounds run parallel to the body's axis, ... [and the patients say,] "I was shot at from a helicopter," then there is a clear link. We cannot say in our communications, ... "These people were shot at from a helicopter." Then one would be at risk of abandoning the principle of neutrality. But if one says one has treated so many people with gunshots along their bodies' axes, then everyone with some knowledge of such conflicts can conclude: 
“They've been shot at from above." And who has helicopters in this area? Then one can establish a link. (author's translation)

The same interviewee told a similar story about discreet ways in which medical aid work can interact, and divide labor, with human rights organizations:

We want to save lives and ameliorate suffering. ... It would be ideal, then, if Human Rights Watch or similar organizations were to take over this political mandate by documenting these things. And we have done that, for example, in 2008 in Abyei ... [when] we had many gunshot wounds in the backs, because they all had to flee. These stories, for example, I told [to] Human Rights Watch representatives. They came to me and inquired about this. Among them was a former MSF worker, and then I said: "Will this report be linked to my name or to MSF?" And she told me that she knew full well that that would be quite disadvantageous for us here and for our project, for the people. She just needed two or three independent confirmations, and then she could report about it. (author's translation)

This example of a division of labor between humanitarian aid and human rights organizations illustrates well that it is problematic to think of aid delivery on the one hand and justice seeking on the other as a zero-sum conflict, even though the respondent was concerned about the potential detriment to MSF programs in the region of bearing witness. This same interviewee expressed strong personal support for the ICC, unlike some of the statements cited above. He even attested to potential positive impact of ICC work on humanitarian workers on the ground: "If there is not justice, when will it end? I personally see the international court as something important. Because I also noticed in Darfur that ... people are afraid of it" (author's translation). This same respondent also distinguished between himself and his convictions as an individual and citizen, on the one hand, and the organization for which he works, on the other:

Somewhere we are also individuals. And, of course, I also try to act within our principles and our charter, as I do act accordingly. When I talk, as head of mission or project leader, with a journalist from [name of local paper], or when you interview me, or when I speak with a representative of the Sudanese authorities, of course. But should I be asked to testify as a citizen, then it is my duty to provide truthful answers.... I have to follow the laws. If it is international law, then I have to obey international law, and that also applies to me as a citizen of my country. (author's translation)

These statements provide two insights. First, besides principled personal opposition to the ICC, some MSF staff and sections support 
judicial intervention generally and in particular welcome, in open or subtle ways, international criminal justice intervention. Second, they also find ways of bearing witness that, through cautious wording, contribute to the message of human rights NGOs and judicial interventions.

One other MSF interviewee expressed support for legal intervention generally. It is not by chance that this respondent is a US citizen (albeit working for a European section) who was trained in international law at a prestigious American university. Remember that among Amnesty International interviewees those with law degrees showed much more unambiguous support for the ICC. Remember also that the United States was immersed in movements that favored the full range of criminal justice interventions, including genocide charges against Omar alBashir. The director-general of a national section, this interviewee is not without influence, and a close look at his position is in order. He first unambiguously confessed to the mandate of témoignage: "You provide pills, blankets, food, medical treatment. But that is essentially a BandAid. And underneath is something else going on and causing it. Children don't naturally have scrap-metal wounds. You try to change the situation by exposing it, confronting perpetrators with their actions.... We see rising levels of malnutrition and we go and confront WFP [the World Food Program] with that. That is the basic idea behind bearing witness." And not just UN agencies should be supplied with information about suffering, according to this interviewee, but also journalists: "If people are coming in and they are starving and . . . they tell you the rains did not come, that is one thing. If they tell you the soldiers have been stealing it-that is another. And very often it is the latter. ... There was a steady flow of MSF press releases, like from other organizations. And that is part of the attempt behind that. It is not promotion of ourselves; it is to try to expose the situation."

This lawyer interviewee indeed went further. His support for bearing witness extended to open support for legal intervention, albeit broadly understood and explicitly including the model of the South African Truth and Reconciliation Commission (for which another MSF interviewee also expressed great sympathy). He also spoke about peace as a potential consequence of the pursuit of justice: "No justice, no peace." While he cited the situation of Charles Taylor and his refusal to bargain in light of the risk of arrest, he said: "I take the side of the victims at some point. That is not an excuse for not pursuing something like justice."

Yet even this American-trained lawyer expressed concerns about potential backlash. Decisions to go public with information about grave 
human rights abuses should-in his mind too-depend on the circumstances. He refers to the example of "Burma, where we've got lots to say and we just don't, because 90 percent of the HIV-AIDS patients receiving anti-retroviral therapy in Burma get it from us. ... We can't afford to be tossed out of that country. There are no other actors to take our place. In Darfur, you know, it is quite apparent that there are other actors." And, beyond this particular situation and despite his relatively open attitude toward justice responses, in the end this MSF interviewee, too, identified with the principle of aid delivery and showed skepticism toward the ICC:

We don't publicize with the goal or objective of attaining justice. But many would, and then use the same facts and figures to do that. And that is a problem now for the aid agencies. It is a problem in fact and it is a problem in perception. If governments or bad actors anywhere perceive you as an agent or [as] anyway related to the pursuit of justice, that creates a barrier, an obstacle to access to populations. And whereas MSF has always pointed its finger at people too, they haven't pointed their finger at individuals. They have pointed their finger at, you know, a government's health care system. . . It is a lot less threatening than an individual believing that you are going to point a finger at him or her directly with evidence for criminal prosecution.... We have had a real discussion in the organization about our relationship to the ICC. In I999, when accepting the Nobel Peace Prize, we called for the ratification [of the ICC], and we've since backed away quite considerably from it.... Bashir is able to justify the expulsion on the ground that these agencies cooperated with the ICC investigation. They are not there to do humanitarian work. They are there to spy on us. Ocampo doesn't help by saying things like "We used data from humanitarian aid agencies to do this." ... We really needed to distance ourselves.

While the goals of delivering aid and securing the affected population's survival and its relationship with the principle of justice dominated the responses of my MSF interviewees, several interlocutors also recognized peace as an important goal. One interviewee, however, perceived a conflict between the pursuit of peace and aid delivery. He referred to the situation in Liberia, where MSF sought to bring relief goods into an area controlled by Charles Taylor, at the same time that the UN sought to build a blockade around Taylor's National Patriotic Front: "There was a real clash between peacemaking, peace enforcing, which was a priority of the United Nations, and providing relief- to the point that, in fact, UN-chartered, or at least UN-sponsored, jet fighters, attacked relief convoys." The same respondent, a person with particular prestige in the organization, was also the lone MSF respondent who 


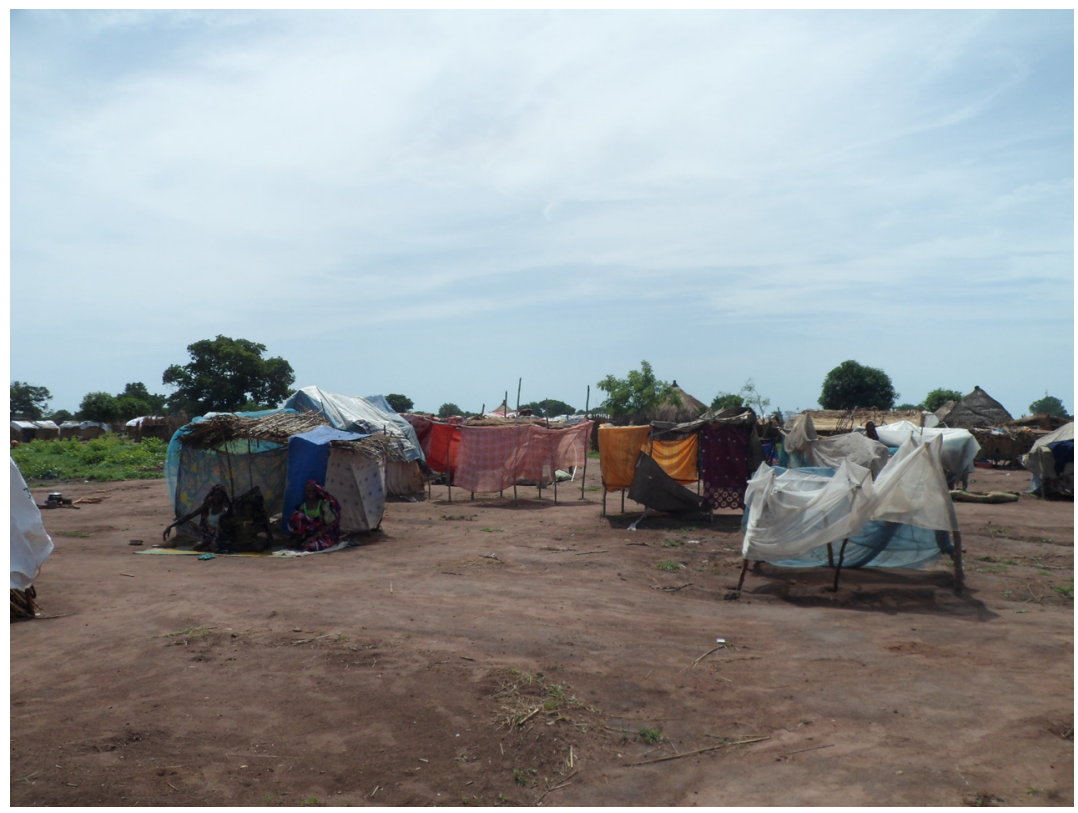

FIGURE II. This image from MSF's website shows displaced Darfuris and their "housing."

saw merit in the principle of national sovereignty: "Well, securing the Sudanese state is, I think, an issue as well. Although I am a doctor without borders, I do believe that states and borders matter. . . . Borders are something that protects a given people, a given society, from imperial strikes."

In short, MSF is an organization dedicated to the delivery of humanitarian, especially medical, aid. It differs from other aid NGOs in that it also engages in témoignage, in bearing witness. Both missions are reflected in our analysis of websites and in my interviews. They are also on display in images I found on MSF websites (see figures II and I2). But the weight of témoignage has fluctuated over time, and it is more pronounced in some sections than in others. Some respondents perceived bearing witness to be in conflict with the primary goal of securing survival. On the ground, however, some sections or staff had discovered "under the radar" methods of collecting and distributing information on grave violations of human rights so that affected victims or human rights NGOs could use it.

In general there is no doubt that MSF is, despite several modifications, a humanitarian aid organization, embedded in a field with specific 


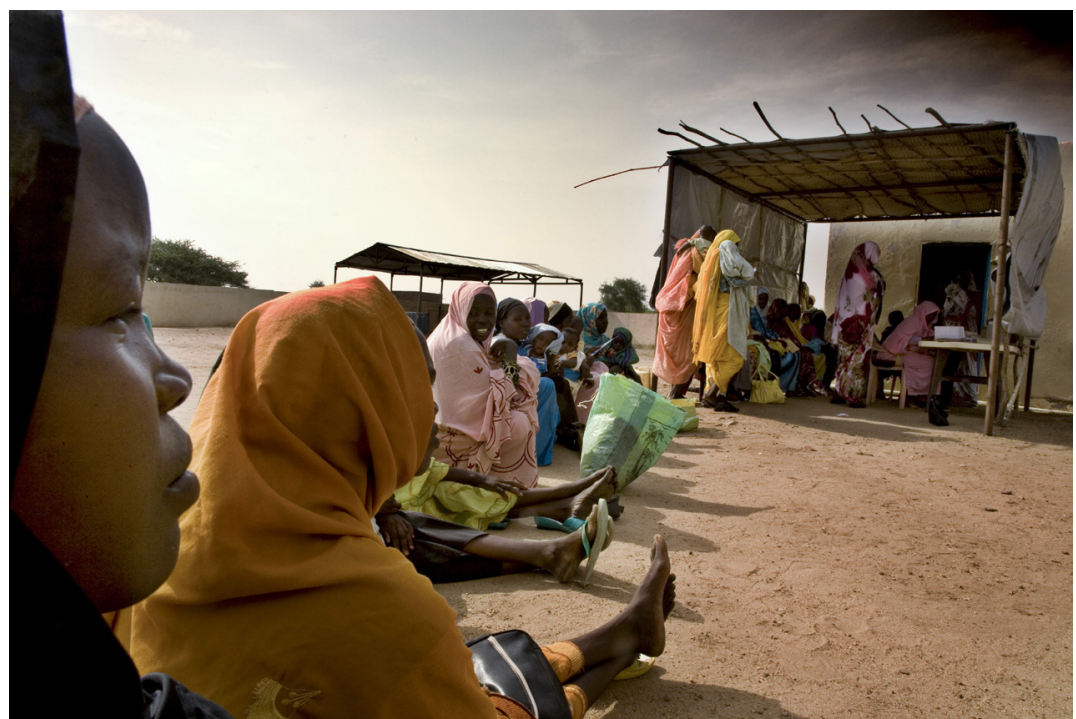

FIGURE I 2. Darfuri women and children at an MSF medical service site, in a photo from MSF's website.

norms and surrounded by a particular set of actors that includes representatives of the perpetrating state, with whom aid NGOs have to collaborate to get their assistance to the affected people. How, then, does this position in the field of humanitarian aid affect MSF workers' narratives about the Darfur conflict?

\section{REPRESENTATIONS OF DARFUR}

Two sources of evidence speak to the ways in which MSF defined the situation in Darfur during the first decade of the twenty-first century. The first is a comparative analysis of documents, press releases, reports from the field, interview transcripts, and position statements, published on websites of the American section of MSF and their Amnesty International and Save Darfur equivalents (for methodological details, see chapter 2 and Zacher, Nyseth Brehm, and Savelsberg 20I4). The second source of data consists of my interviews with MSF staff and volunteers. Interview responses take us backstage and provide insights that go into greater depth and are at least partly freed from constraints of official representations. They come closer to reflecting the genuine mindset of humanitarian aid actors, most of whom have actually experienced the violence and its consequences on the ground in Darfur and interacted 
with agents of the Sudanese state. Not to be mistaken for public pronouncements, they do feed into the conflicted discourses within the organization, and they shine through as communication that, while not formally sanctified, still reaches beyond the organization's boundaries, as we shall see. I organize the MSF representation of Darfur along the same set of dimensions used in the analysis of three academic books (Hagan and Rymond-Richmond 2008; Mamdani 2009a; Flint and de Waal 2008) and of the human rights field: suffering and victimhood; causes and origins of the conflict; actors; and framing.

Interview accounts of suffering and victimhood show substantial overlap with those we encountered in the human rights field. Several interviewees spoke about deaths and enhanced mortality (even mass murder), rape, destroyed villages, lost homes and livelihood, displacement, injuries (specifically scrap-metal wounds), and (in one case) psychological trauma. Our quantitative analysis of the American NGO sections' websites, however, shows noteworthy differences regarding the frequency with which different sorts of suffering are publicized. Compared to Amnesty, MSF Web documents refer to killings and rapes less frequently, but to displacement and destruction of livelihood somewhat more often and to disease and shortages dramatically more frequently. We thus find highlighted, in publicized documents, exactly those types of suffering that call for intervention by humanitarian aid organizations.

Suffering may result from many different causes; and different causal explanations attribute different meanings to suffering. To what degree do MSF actors interpret it as a result of human action, specifically criminal action? Even more precisely, do they refer to criminal actions as constituting human rights crimes, war crimes, crimes against humanity, or genocide? Remarkably, the content analysis of websites shows almost no statements that refer to even one of the types of crimes for which the ICC has jurisdiction. We did, however, find references to behaviors commonly understood as criminal, including murder and rape (Zacher, Nyseth Brehm, and Savelsberg 20I4). These are actually mentioned slightly more frequently on the MSF-USA site than on AmnestyUSA's site. Yet, beyond referring to specific crimes, rarely does the MSF site explicitly categorize the violence as criminal violence, and-againit strictly avoids reference to those types of crime that would fall within the jurisdiction of the ICC. In interviews, too, I find great caution with regard to the use of such terms. As one respondent explained:

In practice, what they [Global South actors] see now in the Western world is [how] . . . these sorts of statements that a government has committed 
violence against its people are so instrumental and are [so] politicized that you just end up looking like a Western actor beating up on [a Global South government]-you know, the double standard-based Western discourse that uses human rights, in some ways, to subordinate the developing world. And you get caught up in the discourse to some extent. So, you know, they believe we really need to distance ourselves from it. And it is very hard, then, to say: "Well but actually the government is committing violence against people."

While humanitarian aid websites and interviewees thus speak freely about the suffering of the people of Darfur, the cautionary note about the use of crime labels is reflected in MSF interviewees' stress of those causes and frames that apply to the conflict but do not invoke the volition of specific actors. The statistical analysis also shows that MSF web documents rarely name offenders. They differ from both Amnesty and Save Darfur particularly in their hesitancy to refer to the Sudanese state as a criminal perpetrator (Zacher, Nyseth Brehm, and Savelsberg 20I4:42). To be sure, MSF interviewees are not uncritical of the Sudanese state. Instead, almost all stressed the center-periphery conflict and the neglect of the periphery by the government in Khartoum as central causes of the conflict. This charge is much in line with the grievances, documented in the famous Black Book (Seekers of Truth and Justice 2004), that played a crucial role in the foundation of the Darfur rebel organizations. One MSF respondent actually cited the Black Book when speaking to the center-periphery conflict in Sudan. But interviewees also emphasized that the current government of Sudan inherited this center-periphery tension from old times, reaching back to the colonial period. "Taking over from the colonial period in the early I950s," one respondent reflected, "it is a very centralized government where power is held by a very small group of people. There was never really an established modernized, modern country.... All the peripheries feel that they are neglected by their government in terms of resources, in terms of representation mainly."

In addition to the neglect of the periphery by the center as the basic source of the Darfur conflict, half of MSF respondents also highlighted a series of secondary conditions for which the government of Sudan is not responsible, among them desertification-the extension of the Sahara Desert southward and the resulting intensified competition for natural resources between herder-nomads and agriculturalists, a competition that breeds violence in combination with other external factors. One interviewee described the situation:

You have issues of local conflict dating back decades if not centuries. . . . More or less it is the nomadic population, competing for grass, for water 
access, with the agricultural group. And this has been the case, tensions and conflicts, traditionally for longer than it is probably written in history. And that desertification, ... . the change of the climate within Darfur has been a factor-plus increasing population pressures-means there has been more competition for land and water, more tensions. The introduction of weapons in Darfur meant that these local conflicts have become more serious, more complicated, and very difficult to resolve with the traditional peacemaking mechanisms. ... You know what happened with the flow of small arms in Darfur, [which is] . . . one of the factors as well. . . . So you have . . . layers of conflict. You have local conflict and then the national-level conflict of the Darfur rebels versus Khartoum. Then you have a regionalization of the conflict as well-Chad, Sudan, Libya. . . . Darfur was and still is a regional conflict, or at least complicated by regional issues. . . . It's a complicated picture, but if you go back to what I said in the beginning: you wouldn't have this type of conflict or the scale of conflict or the disaster you saw in Darfur if there wasn't this problem between the periphery and the center.

While the government of Sudan does appear, in statements such as these, as a contributor to the very background conditions underlying the violence of Darfur, it is also presented as the heir of imperfect state formation that reaches back to colonial days. Further, in the twelve hours of interview material with MSF staff, the government is rarely depicted as contributing to the foreground conditions of criminal violence. Instead, respondents pointed to a series of other complicating factors. One interviewee spoke about the mobilization of Janjawiid militias. While he argued that the government used promises of money and land to lure them into supporting the military, he also stressed that the Janjawiid violence eventually developed an autodynamic and became independent of the government. In this description the government no longer appears as a perpetrator, but as the sorcerer's apprentice who lost control of a process he had initiated: "I think that they [the Janjawiid] just became uncontrollable, that they developed an independent dynamic, that the militias split up into ever smaller groups with distinct interests. The whole process could, in the end, no longer be controlled by the government" (author's translation). Another respondent similarly described a process that ended with "much more localized, fractured violence between all communities." He compared the use of the Janjawiid to a "Pandora's box" that the government had opened but was not able to close again. The American-trained lawyer who among the MSF respondents showed the greatest openness toward justice-focused responses argued similarly. On the one hand, he used categories of international criminal law ("there were crimes against humanity and there were war crimes committed"). On the other hand, he 
challenged the narratives we typically encounter in the human rights field, especially depictions of a clear divide between one group as good and the other as an evil force. Instead this MSF interviewee, like others, stressed patterns of fractionalization and pointed to problematic sideeffects of good-versus-evil narratives: "The simplifications that some social movement actors have engaged in are in part a reinforcement of things that the government of Sudan has done, as it has contributed to creating, it seems to me, those clear ethnic boundaries."

Other interviewees attributed responsibility more squarely to the government of Sudan. Simultaneously, however, they provided explanations, albeit not necessarily justifications, for the actions of the Janjawiid. One respondent questioned the common image of the Janjawiid as a cruel and disorganized horde of killers:

I spoke with a sheik in Kerenik, who told me everything, how that [the violence] unfolded ... that one was flown to Khartoum, lavishly treated and lured into the [government's] agenda. He really told me: "I allowed them to put me to use, more or less, but what was the effect? I lost almost half of my men here, and now I have to take care of their families. The money never arrived. The promises were not kept. We were simply instrumentalized. And now one sees that the abyss is deep." And then he chose his words carefully and said: "Really we do have the same grandmother." (author's translation)

Another respondent similarly spoke to the oppressive conditions of those groups from which militias were recruited. He referred to the government's use of a "counterinsurgency campaign, relying on ... the poor, the poorest against the poor, on mobilized marginal populations of Darfur to fight local insurgencies." The same interviewee simultaneously attributed greater responsibility to rebel groups than is common among human rights activists. And he combined this attribution of agency to rebel groups with a reference to what he considered a problematic approach to the North-South conflict in Sudan and the role played by international diplomacy: "The North-South process has been a trigger. . . . By only taking into consideration the South, it gives the message [that] the only way for all peripheries to be considered was to take up arms and to deal with it in their own terms." Again, the agency of rebel groups as violent actors is underscored, this time as actors who drew inspiration from the North-South negotiations.

Such narratives concerning causes of the conflict complicate, and compete with, the common human rights account of the violence in Darfur. To be sure, MSF respondents in oral communication highlight the same actors as crucial contributors to the violence as we find 
referred to in human rights accounts. References to the "government of Sudan," "political leadership," "Bashir," "the president," the "business and military apparatus," the "army," and the "security apparatus" are frequent throughout the interviews. Also "Arab militias" or "militias equipped by the army" are named. But the role of these actors appears in a different light than it does in human rights narratives. Also, website statements typically avoid reference to any perpetrators, especially the government of Sudan, as responsible for the violence.

One interviewee's reference to "bystanders," the majority of Sudanese who live their lives as though mass killings never took place, sheds an interesting light on the larger domestic context within which NGOs and the Sudanese government operate:

[Nyala in South Darfur] was basically a place where middle-class Sudanese would go for their weekend away from Khartoum, from the big city. And it used to be dotted with all of these cute little B-and-B hotels. . . . You would not know there was a crisis unless you actually went to the camps. Nyala itself is a bustling city of hundreds of thousands of people. It was really bizarre. A similar dynamic is in Khartoum. . . . I was reading the press all the time, reading the newspapers, talking to the relatively educated elite, local reporters, etc.: very little indication that there was a war going on. For me that spoke to the disconnect between the populus and the actions of the government.

A look at framing strategies sheds further light on the interpretation of the events in Darfur by MSF respondents. In my interviews, I again offered four options: a rebellion or insurrection frame (understanding government action as counterinsurgency); a civil war frame; a humanitarian emergency frame; and a state crime frame. Whereas only one Amnesty interviewee clearly supported the insurgency frame, almost all MSF interviewees found this an acceptable interpretation of the violence. Only one rejected it outright, and another expressed skepticism. The civil war frame was more strongly favored by MSF respondents than by their Amnesty counterparts. Astonishingly, though, while almost all Amnesty respondents found the humanitarian catastrophe frame acceptable (much in line with expectations), half of the MSF interviewees expressed caution. For example: "It is the term which I don't like, because it does not say much. I prefer to describe facts. I prefer to say massacres, famine. . . Humanitarian catastrophe is a label which does not tell us very much, except that people are suffering." Another MSF interviewee, like the previously quoted speaker, also from MSFFrance, argued similarly: 
Humanitarian disaster is a tag I never use, because I don't know what it means. ... Is a massacre a humanitarian disaster? Is an earthquake a humanitarian disaster? Is Fukushima a humanitarian disaster? Is Iraq a humanitarian disaster? What is a humanitarian disaster? . . . It is a catchphrase that I never use because it is so vague. . . . I think it is misleading. . . . It is a very recent formulation. As far as I know, that concept or the syntax of the humanitarian crisis was used for the first time in the June '94 resolution of the Security Council, the genocide in Rwanda [resolution]. And the idea was that the word genocide shouldn't be used. So, in order to turn the problem around, they decided that it was a humanitarian crisis. ... It was instrumental to the decision of the White House not to use the G-word. So the G-word was a humanitarian crisis. It was a lie.

Not surprisingly, though, MSF interviewees did not find the state crime frame appropriate for an interpretation of the violence in Darfur. In fact, while all Amnesty respondents wholeheartedly embraced this frame, I found great skepticism among MSF staff. Only two respondents were somewhat supportive, but even one of these stressed that this was his personal opinion: "That is always what we are asked to avoid as employees of Doctors Without Borders: to position ourselves and to say this is state crime or this is genocide. We talk about a humanitarian catastrophe [but see interview statements above]. Where that comes from and what its causes are, on that we may have our personal opinions, but those will not be released to the public. I personally can say about that [definition as crime]: 'yes'" (author's translation).

One other interviewee rejected the notion of state crime and drew a distinction:

I think it is a state that uses violence, commits crimes, but ... what state doesn't? And I think the Sudanese state has committed more of them, but I don't think it is a useful way of understanding the state. I think it is certainly a way of understanding certain actors in the state... . Partly because the state is fairly enormous here. The ministry of health isn't criminal. The ministry of agriculture isn't criminal. [When challenged with the fact that the Nazi state, too, included government agencies not directly involved in the commission of crimes, he responded:] I don't think here [in Sudan] the strategic objectives were criminal. I believe the methods and tactics they used were quite criminal.

One MSF respondent did not reject the notion that crimes were committed, but he insisted that the state crime frame does not adequately capture the events in Darfur: "It is much more than state crimes.... It is a rebellion. It is a political movement. It carries a social and political dynamic.... All this belongs to the concept of rebellion, civil war, political 
movement." What is at stake here is a perceived contrast between a criminalizing frame and an interpretation of the conflict as political.

Another MSF interviewee rejected the state crime frame outright. Much in line with the foregoing statement, he deferred to lawyers' and courts' decisions about the criminal nature of the violence. To my question whether he would also "negotiate with the devil" to get humanitarian aid on the ground, he replied:

What is the devil? Good and bad-we don't necessarily see the world in that way. As a person coming from a different background you have your personal opinions on those sorts of things. But as an organization we don't, and that is something we defend very strongly. On Iraq, I did a round of meetings with the State Department, with the Pentagon, . . . and I challenged them with that. I said, "Do you have a problem with us having communication and links with terrorist organizations, Al Qaida, insurgent groups in Iraq, and so forth?" ... We need it [communication], because to be present in an area you need acceptance by the groups.

The foregoing statement brings us full circle to the notion of the humanitarian aid field and the ways in which this field structures knowledge and basic categories of thought. To be sure, things are not clear-cut, especially for a humanitarian aid NGO such as MSF with its dedication to bearing witness. MSF actors surely do not downplay the suffering of the Darfuri population. To the contrary, they produce-through medical examination and published records and reports_evidence of such suffering, evidence that may later be put to use in criminal court proceedings and that is feared by representatives of the Sudanese state. Interviewees also named all the actors involved in the violence. Their narrative does not differ substantially, in this respect, from that of human rights campaigns.

Yet the representation assembled from my interviews with MSF staff and our content analysis of the MSF-USA website suggests that the identification of causes and the framing of the violence differ substantially between human rights and humanitarian aid organizations and their agents. Again, responses from the latter interviewees emphasize natural conditions more strongly than do human rights narratives. And, while they surely hold militia groups responsible for atrocities, MSF respondents also interpret them as victims of resource shortage, neglect, and the Sudanese state's false promises. Rebel groups instead are considered in a somewhat more critical light than is common in the context of human rights campaigns.

Both human rights and humanitarian actors blame the state, but the attribution is much more indirect among MSF personnel. The latter see 
the state more as a contributor to long-standing background factors, as opposed to highlighting contemporary state strategies as foreground factors and direct causes of violence. Further, they break the state up into components, only some of which bear responsibility. Finally, the crime frame is generally not regarded as satisfactory, and judgments on criminal responsibility are left to lawyers and the courts. This is in line with our comparative quantitative analysis of framing strategies used by the American section of MSF. Here too the explicit crime frame is rarely used, the state is almost never referred to as a perpetrator, and support for international prosecution is missing altogether (Zacher, Nyseth Brehm, and Savelsberg 20I4:42). In short, MSF-a prominent example of an INGO in the humanitarian aid field, in which the Sudanese state is a crucial player-is an important producer of representations of the Darfur conflict and contributes significantly to the definition of the situation. Its representation differs substantially from the one we encountered in our examination of the center and the periphery of the human rights field.

\section{COMMUNICATING REPRESENTATIONS}

Representations of mass violence that grow out of humanitarian aidoriented NGOs matter, not least because they can contribute to shaping public opinion and to challenging human rights narratives in the public sphere. This applies to official pronouncements and NGO reports as well as to opinion formation among NGO staff and volunteers. My interviews with journalists indicate that NGOs are crucial sources of information, a theme to which I return in greater detail below. Interviews with MSF staff confirm this notion. Specifically, they spell out at least four pathways by which humanitarian NGO narratives may reach those who report about the conflict to broad audiences across the globe.

First, not surprisingly, communication is used strategically by MSF sections of different countries. One interviewee, a "manager of medical and humanitarian communications," described these efforts: "We want to make sure it [public communication] is in line with our medical and operational priorities. . . . We really want our public events to have a strategic element; that means targeting better audiences, whether they are medical or academic or diplomatic or NGO communities."

Second, diffusion of MSF representations also occurs in the field. A "crisis communications manager" who was serving MSF in Khartoum 
in the summer of 2004 described the issuing of a press release entitled "No Relief in Sight." то The release was based on a retrospective mortality survey and accompanied by an epidemiological report. It was ready for posting at the exact time when UN secretary-general Kofi Annan und US secretary of state Colin Powell came to Khartoum. "I was in West Darfur, and there was a big scramble to get me back to Khartoum because there was going to be the entire press corps, following Colin Powell. And I remember coming into the press room, just walking from one person to the other and handing out our press release, the 'No Relief in Sight.' And I believe it was quoted a lot in those initial stories." Chapter 9 offers a detailed analysis of the actual effects of this particular initiative on media reporting.

Third, communication with journalists arises within opportunity structures in the field. Speaking about Nicholas Kristof of the New York Times, one interviewee reported: "He visited with a lot of MSF teams in Darfur and we helped arrange that. We helped arrange briefings for him in the early days." Also, "Christiane Amanpour [of CNN] stayed in our compound because there was nowhere else to stay. So she threw down her sleeping bag inside of our compound and during the day would go out and do reports." These partially accidental contacts in the field are nevertheless structured.

Fourth, spontaneous encounters are supplemented by planned interactions with the media. One respondent reported that MSF held editorial board meetings on the subject of Darfur with the New York Times, first in 2004 and again in 2006 or 2008.

Cautionary notes are in order, though. First, while humanitarian NGOs obviously have several channels of communication to the media (and to actors from other sectors in public life), as illustrated here for MSF, their capability to impress on journalists the humanitarian aid definition of the situation is limited. I have already cited Kristof and the New York Times with their embrace of the genocide frame for Darfur, as well as Kristof's generous use of Holocaust analogies to shed light on the situation in Darfur. Humanitarian aid NGOs may thus feed information to journalists, but the media put this information to use according to their own rules. The degree to, and the ways through, which NGO representations translate into media reports warrants further empirical examination, which I offer in later chapters.

Second, if we encounter nation-specific discourses even in a rather centralized rights-oriented NGO such as Amnesty, a more decentralized humanitarian NGO will have to face inner conflict in its attempt 
to define a situation. Competing representations may thus reach the public, as should be obvious in the account provided thus far.

Finally and crucially, however, even as humanitarian aid INGOs such as MSF release information about the suffering of the local population in conflict zones, they will always be mindful of the government as an essential actor in the field in which they have to operate. In the words of one interviewee: "We try to be transparent. We provide the government with our press releases, or at least inform them that we are going to communicate publically on an issue." "I Such considerateness should not come as a surprise given the organization's dependency on permits and cooperation by the state. As we have seen, this policy of restraint does not keep the aid NGO from displaying the suffering, but suggests causal interpretations and a frame that advances interpretations of violence of a very different nature from those emanating from the human rights field.

\section{CONCLUSIONS}

The humanitarian aid field and the INGOs within it, here examined for the case of MSF, obviously take a different shape from the human rights field. The government of the aid-receiving country is a major player in the aid field. In our case this is the government of Sudan, leading representatives of which have been charged with the gravest of crimes by the ICC. INGOs have to deal directly with the government of the receiving country-even MSF with its insistence on independence from governments at home and abroad.

In line with our expectations about the relationship between the characteristics of fields on the one hand and the knowledge repertoires generated by them on the other, we also see that the representation of the Darfur conflict takes distinctive shape in the humanitarian aid world. To be sure, this is not a world in which suffering is denied. To the contrary, the population's pain and deprivation in areas of conflict is not just acknowledged but also documented, at times dramatized, and communicated to a world audience, in both words and images. Those aspects of the suffering, however, that can be addressed by humanitarian aid programs are the ones most likely to being highlighted. That observation would apply to displacements and to deprivations in IDP or refugee camps more than to the mass killings by military and militia or rebel groups. Starker than this difference are those of representations of actors and the framing of the violence. Generally, aid narratives 
treat the government of Sudan with greater caution. Long-term policies that contributed to laying the groundwork for the current violence, especially the neglect of the country's periphery, are most certainly highlighted, while short-term actions that more directly caused the violence are more commonly downplayed. Respondents typically attribute causal primacy for the outbreak of violence to the rebel groups-even if government responses are termed disproportionate and escalating. In line with such caution, actors in the aid field are reluctant to choose the state crime frame. Most stress instead the supremacy of the humanitarian catastrophe frame. Responses to questions about the insurgency and civil war frame are ambiguous. Actors in the humanitarian aid field are especially reluctant to apply the term genocide to the conflict, a label that so much dominated the criminal justice-oriented discourse, particularly in the United States.

Clearly, what we diagnose as an elective affinity between the humanitarian aid field and the representation of the violence by aid actors involves causal ties. Depending on the cooperation of the Sudanese state in the granting of visas and permits to travel and deliver aid, humanitarian actors apply caution with regard to the government of Sudan.

Why, then, do we not find in the aid field a pure ideal-typical depiction of a humanitarian catastrophe? Note that MSF, the aid INGO selected for this in-depth study, is also dedicated to bearing witness. In that sense I made a conservative choice when seeking to demonstrate the emergence of an aid-oriented representation. Other aid INGOs should display a narrative even closer to an ideal type of humanitarian representation. In addition, fields are never pure. They overlap, or interpenetrate, with other fields, as when lawyers are being recruited into leading positions within the humanitarian aid field, especially lawyers socialized in a country with a strong criminal justice tradition such as the United States. Remember that even within the human rights field, lawyers embraced the logic of the justice cascade more unambiguously than members of other professions.

The empirical analysis also speaks to the ability of international institutions to create a global representation of mass violence, a theme that relates to debates between the World Polity School, with its focus on global scripts, versus its challengers that highlight national contexts and organization-specific constructions of knowledge. In support of the World Polity School we witnessed the emergence of a global understanding of the conflict in Darfur within the humanitarian aid field. Yet, just as we observed national specifics in sections of INGOs in the 
human rights field, the humanitarian aid INGO examined here, less centralized in its organizations, shows even greater discrepancies across national sections.

Finally, linking insights from this chapter with observations from the preceding ones, we see competition between two distinct scripts-those emerging from the human rights field and others generated by the humanitarian aid field. Clearly, we observe an intense competition over the representation of the Darfur conflict across fields. At times, however, this competition gives way to a division of labor, whereby a humanitarian organization produces evidence of suffering that may be used by human rights organizations to draw conclusions regarding criminal responsibility for the suffering. The competition between the two fields should thus not be misunderstood as a zero-sum conflict.

In addition to humanitarian INGOs, states may also focus on humanitarian aid delivery, often in close interaction with NGOs. Ireland is a fascinating case in point. I address this example in the following chapter, where I call the close networks of humanitarian NGOs, government institutions, and other actors a "humanitarian complex" and examine the effects of this complex on the representation of mass violence in Darfur. 